\title{
Variasi Retorika dalam Pertunjukan Wayang Cenk Blonk
}

\section{Gusti Ngurah Gumana Putra}

\author{
Program Studi Seni Pedalangan, Fakultas Seni Pertunjukan \\ Institut Seni Indonesia Denpasar, Jalan Nusa Indah \\ Denpasar 80235, Indonesia
}

gumjuse@gmail.com

Tujuan penelitian ini adalah untuk penguatan aspek retorika dalam pertunjukan wayang kulit. Hal ini diharapkan dapat memberikan manfaat agar seniman wayang kulit khususnya mahasiswa Seni Pedalangan ISI Denpasar bisa memformulasikan suatu lakon pertunjukan wayang yang menarik, sehingga lebih mudah dalam menyampaikan isi, tujuan dan maksud, serta makna/ nilai-nilai luhur pertunjukan wayang kepada audience yang notabene merupakan masyarakat multikultural, tanpa harus menenggelamkan bahasa Bali sebagai bahasa daerah seniman dalang sendiri. Aspek retorika sangat penting untuk ditelaah. Pada kesempatan ini, aspek tersebut menyangkut variasi retorika, yang digali dalam pertunjukan wayang kulit Cenk Blonk. Penelitian ini merupakan penelitian deskriptif kualitatif. Sumber data diperoleh melalui perekaman dan penelaahan hasil-hasil rekaman pertunjukan wayang kulit dengan metode kepustakaan yang didukung dengan wawancara terhadap seniman dalang wayang Cenk Blonk. Untuk mendapatkan kualitas dan kuantitas data yang kaya dan variatif, dilakukan pula penelaahan video-video pendek terbaru wayang Cenk Blonk yang beredar di youtube, dan jika diperlukan, dilakukan pula perekaman pementasan wayang secara insidental. Data dianalisis dengan metode kepustakaan dan metode padan yang dijabarkan melalui teknik menghubungbandingkan unsur yang terdapat di dalam maupun di luar bahasa. Adapun hasil yang diperoleh menunjukkan bahwa, dalang Cenk Blonk memiliki kreativitas dalam menuangkan pokok pikirannya melalui sebuah lakon inovatif dengan gaya dan variasi retorika yang menarik. Penggunaan diksi dan gaya bahasa yang membangun retorika dalang Cenk Blonk ternyata dapat menciptakan kualitas yang tinggi dari lakonnya sehingga menarik untuk dinikmati. Aspek diksi atau pilihan kata yang digunakan meliputi alih kode dan campur kode bahasa, tingkatan tutur bahasa Bali/ Anggah-Ungguhing Basa Bali, dan abreviasi yang terbagi menjadi akronim dan lakuran/ portmanteau. Sedangkan pada aspek gaya bahasa, dalang Cenk Blonk menggunakan beberapa jenis bahasa figuratif yaitu gaya bahasa simile dan gaya bahasa ironi.

Kata kunci: retorika, wayang cenk blonk

The purpose of this study is to strengthen the rhetorical aspect of wayang kulit performances. This is expected to provide benefits so that wayang kulit artists, especially students of Pedalangan ISI Denpasar, can formulate an interesting puppet show play, making it easier to convey the content, goals and intentions, as well as the meaning / noble values of wayang performances to the audience who incidentally is the public. multicultural, without having to drown the Balinese language as the local language of the dalang artist himself. The rhetorical aspect is very important to apply. On this occasion, this aspect concerns the rhetorical variations, which are explored in the Cenk Blonk shadow puppet show. This research is a qualitative descriptive study. Sources of data were obtained through recording and reviewing the results of the recording of wayang kulit performances using the bibliography method supported by interviews with the puppeteer artist Cenk Blonk. In order to obtain rich and varied quality and quantity of data, a review of the latest short videos of the Cenk Blonk puppets circulating on YouTube, and if any and necessary, incidental recordings of wayang performances also be conducted. The data were analyzed by the library method and the equivalent method which were described through the technique of comparing the elements contained within 
and outside the language. The results obtained indicate that the puppeteer Cenk Blonk has creativity in expressing his thoughts through an innovative play with interesting rhetorical styles and variations. The use of diction and language style that builds the rhetoric of the puppeteer Cenk Blonk can actually create a high quality of the play so that it is interesting to enjoy. Aspects of diction or word choice used include code switching and language code mixing, speech levels in Balinese/ Anggah-Ungguhing Basa Bali, and abbreviations which are divided into acronyms and portmanteau. While in the aspect of , the puppeteer Cenk Blonk uses several types of figurative language, namely simile style and irony style.

Keywords: rhetoric, wayang cenk blonk

Proses review: 1 - 15 September 2021, Dinyatakan lolos 17 September 2021

\section{PENDAHULUAN}

Seorang seniman dalang di Bali dalam menyajikan pertunjukan wayang kulit tidak bisa terlepas dari aspek-aspek bahasa dan sastra. Bahasa merupakan media penyampaian informasi yang terkandung dalam lakon pertunjukan. Bahasa yang digunakan pada umumnya adalah bahasa Kawi, bahasa Bali, dan tidak sedikit pula menggunakan unsur bahasa lain seperti bahasa Indonesia maupun bahasa asing lainnya. Bahasa memegang peranan penting dalam pertunjukan wayang kulit. Informasi yang merupakan inti pikiran seorang dalang dapat disampaikan melalui bahasa yang digunakannya dalam pertunjukan. Penyampaian bahasa yang baik dan benar, mampu menciptakan suatu lakon yang berkualitas. Dengan adanya kualitas ini maka minat dan antusias dari penonton untuk menikmati pertunjukan wayang kulit akan lebih meningkat. Hal tersebut juga dapat mempengaruhi sikap mental dan kejiwaan dari penonton pertunjukan wayang kulit untuk dapat dengan mudah menerima pokok pikiran yang disampaikan oleh seniman dalang. Dengan demikian, seorang dalang dapat dikatakan memahami esensi gaya dan kesenian berbicara melalui lakon pertunjukan wayang kulit. Selain itu, seorang seniman dalang juga harus menguasai dengan baik pengetahuan tentang sastra. Hal ini sangat berguna karena lakon pertunjukan wayang yang disajikan bersumber dari kesusastraan Jawa Kuna yang hingga saat ini dimiliki dan digunakan oleh masyarakat Bali.

Kesenian atau gaya berbicara merupakan hal yang sangat diperlukan oleh seorang seniman dalang dalam upaya meningkatkan kualitasnya. Tanpa kemahiran yang mumpuni dalam berbicara atau berbahasa, seniman dalang tidak akan mampu menunjukkan penjiwaan yang memadai dalam lakon yang dipertunjukkan melalui tiap tokoh yang dibawakannya. Pentingnya kesenian dalam berbahasa pada saat melakonkan pertunjukan wayang adalah sebagai modal utama dari seorang seniman dalang agar dapat memenangi hati para penikmat maupun penonton pertunjukan wayang. Dengan memenangi hati para penonton, maka secara otomatis seorang seniman dalang tersebut juga dapat memenangi pangsa pasar baik di kancah regional, nasional, maupun internasional.

Salah seorang seniman dalang yang berhasil memenangi pangsa pasar dikarenakan oleh kemumpunian keahliannya dalam berbahasa pada saat melakonkan seni pertunjukan wayang kulit adalah dalang I Wayan Nardayana atau lebih akrab disebut dengan dalang Cenk Blonk. Nardayana, yang untuk selanjutnya akan disebut dengan 'Dalang Cenk Blonk', adalah seorang seniman dalang yang hingga saat ini mampu berkreasi dan berimprovisasi mengikuti perkembangan zaman. Kemunculan seorang Dalang Cenk Blonk mampu mengikat hati masyarakat Bali ditengah-tengah situasi dunia pewayangan yang agak kurang mendapat perhatian di masyarakat pada saat itu. Kurangnya perhatian dan minat masyarakat terhadap pementasan wayang kulit disebabkan oleh rasa bosan masyarakat terhadap karakter wayang yang tidak pernah berubah. Selain itu, arus informasi, kemajuan ilmu pengetahuan dan teknologi yang semakin masiv juga mengurangi minat masyarakat untuk menonton pertunjukan wayang kulit. Akan tetapi, dengan kehadiran Dalang Cenk Blonk, minat masyarakat 
Bali terhadap pertunjukan wayang kulit menjadi lebih meningkat. Hal ini disebabkan karena Sang Dalang mampu mengemas suatu lakon pertunjukan yang menarik untuk ditonton dengan retorika bahasa yang kreatif .

Model yang dikemas oleh Dalang Cenk Blonk adalah suatu pembaharuan dalam dunia pewayangan Bali. Adapun unsur-unsur pagelaran seperti unsur gamelan, tata suara, tetikesan (gerak wayang di kelir), tata cahaya, serta tema-tema cerita yang disuguhkan adalah suatu inovasi yang mampu membangkitkan ruh dari suatu pementasan wayang kulit. Selain itu, gaya bahasa dialog dan monolog yang disajikan dalam setiap pementasannya sarat akan hiburan yang secara tidak langsung mengikat nilainilai luhur yang bersifat pendidikan, keagamaan, sastra, sosial, dan politik. Selain itu, dia juga banyak menyerukan kecaman ataupun sindiran yang dikemas dalam bentuk lelucon-lelucon pada dialog maupun monolog para tokoh punakawan (Budiasa, 2008: 229). Dengan adanya refleksi kehidupan nyata di masyarakat dalam setiap adegan pertunjukan wayang yang dibawakan, dia mampu menarik alam bawah sadar dari penonton untuk ikut menjiwai setiap adegan yang dimainkan. Dalang Cenk Blonk sangat cakap dan terampil di dalam mengolah setiap kata-kata yang dituturkan melalui teknik antawacana pedalangan yang kreatif dan inovatif. Kedua hal tersebut dikolaborasikan olehnya melalui lakon pertunjukan wayang kulit, sehingga lakon pertunjukan yang dibawakannya menjadi sangat menarik dan diminati oleh masyarakat penikmat seni pertunjukan wayang kulit.

Gaya maupun kesenian dalam berbicara oleh seorang seniman dalang untuk seterusnya akan disebut dengan retorika seniman dalang, adalah kemampuan penggunaan bahasa oleh seorang dalang ketika mementaskan suatu lakon pertunjukan wayang kulit. Retorika yang diperlihatkan oleh Dalang Cenk Blonk merupakan suatu kemampuan yang tinggi dalam berbahasa. Dia mampu mengolah bahasa yang digunakan dengan baik melalui tokohtokoh pewayangan, sehingga pertunjukan wayang menjadi menarik dan diminati. Dalang Cenk Blonk memiliki gaya Retorika yang khas dalam setiap lakon pertunjukan wayang kulityang dibawakannya. Sejauh ini, Retorika Nardayana dalam lakon pertunjukan wayang yang dibawakan dapat diketahui merupakan variasi yang bertitik tolak pada pilihan kata / diksi yang antara lain meliputi alih kode dan campur kode bahasa, abreviasi dalam bahasa Bali, dan variasi tingkatan dalam bahasa Bali/ Anggah-ungguhing Basa Bali. Ketiga unsur diksi di atas merupakan unsur pembangun Retorika Dalang Cenk Blonk ketika mementaskan pertunjukan wayang. Selain diksi, gaya bahasa pun menjadi unsur pendukung yang membangun gaya retorikanya.

Melihat tema yang dikemukakan dalam tulisan ini, maka teori yang tepat untuk digunakan adalah teori Sosiolingusitik. Teori Sosiolinguistik beranggapan bahwa pemakaian bahasa pada umumnya tidak pernah bersifat homogen atau tidak monoton, tetapi berlangsung atas sejumlah ragam atau varian. Teori Sosiolinguistik mencoba menemukan aturan-aturan yang berhubungan dengan masyarakat dan menjelaskan hubungan antara karakteristik bahasa di masyarakat menyangkut ketetapan dan memilih variasi dan ragam bahasa dengan mempertimbangkan faktor-faktor situasi seperti partisipan / peserta pembicaraan, situasi pembicaraan, ranah pembicaraan, dan lain sebagainya yang merupakan faktor-faktor di luar lingkungan bahasa. Sosiolinguistik merupakan salah satu teori bidang ilmu bahasa yang membahas dan mempelajari aspek-aspek khususnya variasi-variasi dan peristiwa bahasa yang berkaitan dengan faktorfaktor kemasyarakatan. Hymes yang dikutip oleh Rahadi (2001: 29-35) telah menunjukkan adanya 8 komponen yang dianggapnya berpengaruh terhadap pemilihan variasi dalam bertutur. Kedelapan komponen tersebut kemudian diakronimkan dengan SPEAKING yaitu:

Setting digunakan untuk menunjuk pada aspek tempat dan waktu terjadinya sebuah tuturan. Secara umum faktor ini menunjuk kepada keadaan dan lingkungan fisik tempat tuturan itu terjadi;

Participants (peserta tutur) dapat dipakai untuk menunjuk kepada minimal dua pihak dalam bertutur yakni penutur dan mitra tutur;

Ends (tujuan pembicaraan). Sebuah tuturan dimaksudkan untuk menyampaikan informasi atau buah pikiran serta dapat pula dipakai untuk membujuk, merayu, mendapatkan kesan dan sebagainya;

Act (pokok tuturan) merupakan bagian komponen tutur yang tidak pernah tetap, artinya tuturan itu akan selalu berubah-ubah dalam deretan pokokpokok tuturan dalam peristiwa tutur; 
Key (nada tutur) menunjuk kepada nada, cara, dan motivasi di mana suatu tindakan dapat dilakukan dalam bertutur. Nada tutur dapat dibedakan menjadi nada tutur yang bersifat verbal maupun nonverbal. Nada tutur verbal dapat berupa intonasi, cara, dan motivasi yang menunjuk pada warna santai, serius, tegang, kasar, dan sebagainya;

Instrumentalistis (sarana tutur) menunjuk pada saluran tutur dan bentuk tutur. Saluran tutur adalah alat di mana tuturan itu dapat dimunculkan oleh penutur dan sampai kepada mitra tutur. Sarana yang dimaksud dapat berupa saluran lisan, saluran tertulis, bahkan dapat pula lewat sandi-sandi atau kode tertentu;

Norms (norma tutur) dibedakan atas dua hal yakni norma interaksi dan norma interpretasi dalam bertutur;

Genre (jenis tutur) menunjuk kepada jenis kategori kebahasaan yang sedang dituturkan. Maksudnya adalah bahwa jenis tutur itu akan menyangkut kategori wacana, seperti percakapan, cerita, pidato, dan semacamnya.

Terjadinya variasi retorika terkait dengan pemilihan kata/ diksi dan gaya bahasa dapat disebabkan oleh berbagai faktor, baik faktor dalam bahasa maupun faktor luar bahasa yang sifatnya sosiosituasional. Faktor yang biasanya menyebabkan terjadinya peristiwa penggunaan variasi retorika berbahasa adalah partisipan, topik pembicaraaan, suasana dan situasi, bahasa yang dikuasai oleh partisipan, dan adanya maksud-maksud tertentu yang ingin dicapai oleh partisipan. Teori sosiolinguistik yang konsepnya mengacu kepada konsep retorika, dianggap tepat untuk dijadikan sebagai dasar analisis variasi retorika dalam seni pertunjukan wayang Cenk Blonk. Retorika pewayangan pada prinsipnya merupakan sikap pemilihan dan pemakaian bahasa dalam pertunjukan yang terimplementasi ke dalam sebuah antawacana dalam pertunjukan wayang kulit.

Tulisan ini diharapkan dapat memberikan kontribusi terhadap seni pedalangan. Hal ini dikarenakan banyaknya seniman dalang wayang kulit di Bali khususnya seniman dalang yang merupakan lulusan baru Seni Pedalangan yang dianggap masih kurang mumpuni dalam penguasaan Retorika, sehingga perlu untuk dibina kemampuan retorikanya dalam mengantarkan seni pertunjukan wayang kulit ke arah popularisasi sesuai dengan perkembangan era globalisasi. Selain itu, tulisan ini juga dapat dijadikan sebagai metode pembelajaran bagi mahasiswa penutur bahasa Bali pada umumnya, dan mahasiswa jurusan Seni Pedalangan khususnya agar lebih memahami bahasa Bali dan penggunaannya dalam berbagai aspek kehidupan. Pada kesempatan ini, kefasihan berbahasa Bali dan kemampuan Retorika diharapkan dapat lebih ditingkatkan. Melalui pemahaman yang lebih baik terhadap bahasa Bali, kefasihan dalam penggunaannya, kemampuan yang mumpuni dalam retorika, sudah tentu dapat mendukung pelestarian bahasa Bali di kalangan masyarakat penutur bahasa Bali secara umum dan di kalangan seniman dalang khususnya lulusan Jurusan Seni Pedalangan Fakultas Seni Pertunjukan ISI Denpasar.

\section{METODE PENELITIAN}

Penelitian ini menggunakan data primer yang memiliki fungsi dan kedudukan sebagai data utama dalam sumber analisis. Berkenaan dengan hal itu, yang dijadikan sumber data primer dalam penelitian ini adalah; 1) data lisan yang didapat langsung melalui perekaman pertunjukan wayang kulit inovatif, 2) data tulis yang didapatkan melalui transkripsi dan transliterasi dari konten kepingan DVD pertunjukan wayang kulit yang telah ada, dan 3) data tulis hasil wawancara terhadap informan yaitu dalang Wayang Kulit Cenk Blonk atau I Wayan Nardayana (Alumni Prodi Seni Pedalangan FSP ISI Denpasar).

Sumber data tersebut dikumpulkan dengan metode observasi, dokumentasi, wawancara, dan pencatatan. Dalam hal ini, peneliti berperan sebagai instrumen penelitian. Sampel ditentukan dengan purposive sampling yaitu memperhatikan pertimbangan tertentu yang dapat memberikan data secara maksimal. Berkenaan dengan pengumpulan data melalui teknik wawancara, peneliti menyiapkan beberapa instrumen seperti daftar pertanyaan. Data yang dikumpulkan lebih terfokus pada data yang berasal dari rekaman pertunjukan wayang kulit inovatif yang sempat didapatkan sebelumnya dan data yang berasal dari rekaman DVD pertunjukan wayang kulit inovatif (Wayang Cenk Blonk), dan video-video Wayang Cenk Blonk yang tersedia di youtube.

Penelaahan data dilakukan dengan mengikutsertakan kembali proses pengumpulan data secara direct 
sesuai dengan yang telah disampaikan pada tahap pengumpulan data di atas. Analisis data pada kurun waktu ini langsung akan dicatat dan nantinya akan menghasilkan draf atau konsep awal dari hasil penelitian yang merupakan luaran penelitian. Adapun Teknik yang digunakan dalam tahap analisis adalah teknik terjemahan. Penyusunan hasil analisis data kemudian dilakukan. Pada tahap ini pula, dilakukan klarifikasi kembali terhadap informan mengenai halhal yang berkaitan dengan data yang telah diperoleh. Klarifikasi dilakukan kepada dalang wayang Cenk Blonk. Data yang diperoleh dari pertunjukan wayang Cenk Blonk ditanyakan kembali kepada narasumber yang bersangkutan mengenai hal yang berkaitan dengan sebab terjadinya pola data seperti itu. Hal ini dilakukan untuk menguji hipotesis yang telah didapatkan.

\section{ANALISIS DAN INTERPRETASI DATA}

\section{Pilihan Kata (Diksi) dalam Pertunjukan Wayang Cenk Blonk}

Pilihan kata biasanya digunakan untuk menyampaikan suatu makna kepada orang lain sesuai dengan keinginan penulis/ pembicara. Dalam hal ini, pemilihan kata disebut sebagai diksi. Syarat suatu diksi adalah memilih dan menggunakan kata dengan tepat, benar, dan lazim. Pemilihan diksi yang tidak tepat menyebabkan perbedaan makna dan pesan penulis tidak tersampaikan. Aspek kata di dalam diksi meliputi denotasi, konotasi, morfologi, dan semantik. Para penyair dan seniman biasanya menggunakan diksi untuk memperoleh makna puitis tertentu. Penggunaan diksi yaitu untuk mendapatkan makna setepat-tepatnya terhadap banyak pernyataan. Diksi yang tepat akan menimbulkan imajinasi yang memiliki estetika dan nilai puistis serta estetis. Penerapan diksi yang paling dasar adalah pada pengungkapan gagasan penulis/ pembicara. Diksi sering diterapkan pada saat berbicara di depan publik maupun untuk menulis beragam karangan khususnya dalam penulisan naskah pertunjukan wayang. Penggunaan ketepatan pilihan kata ini dipengaruhi oleh kemampuan pengguna bahasa yang terkait dengan kemampuan mengetahui, memahami, menguasai, dan menggunakan sejumlah kosakata secara aktif. Dewasa ini, diksi berkaitan dengan pilihan kata yang tepat pada situasi, tujuan, dan partisipan yang tepat. Diksi pada pertunjukan wayang Cenk Blonk, dapat diklasifikasikan dan divariasikan menjadi beberapa kategori di bawah ini.

\section{Campur Kode (Code Mixxing)}

Campur kode adalah suatu gejala bahasa pada masyarakat multilingualisme. Multilingualisme adalah adanya kondisi penggunaan lebih dari dua bahasa atau unsur bahasa dalam kehidupan masyarakat. Gejala ini terjadi di semua bidang kehidupan masyarakat Bali. Secara khusus, kehidupan berkesenian juga menjadi ranah terjadinya multilingualisme. Seni pertunjukan yang menggunakan bahasa sebagai medianya sangat berpotensi mengalami gejala ini. Salah satu ciri yang dapat dilihat dari sini yaitu terjadinya campur kode bahasa. Campur kode merupakan akibat dari adanya saling ketergantungan bahasa dalam kehidupan multilingualisme. Campur kode memiliki pengertian sebagai penggunaan unsur bahasa berbeda dalam tuturan bahasa pertama yang digunakan. Unsur tersebut bisa berupa kata, istilah, maupun frase. Campur kode memiliki fungsi tertentu sehingga hal ini bisa terjadi. Pertunjukan wayang Cenk Blonk adalah seni pertunjukan wayang yang memiliki ciri khas retorika yang istimewa. Khazanah bilingualisme dan multilingualisme sangat kentara dalam setiap ujaran dialog maupun monolog tokoh-tokohnnya. Variasi sejenis campur kode ini sangat banyak ditemukan dalam lakon-lakon yang dibawakan oleh dalang Cenk Blonk. Hal ini dikarenakan oleh berbagai hal, dan dapat memberikan manfaat timbal balik bagi dalang sendiri dan bagi para penonton. Dalang dan penonton adalah partisipan tutur dalam ranah ini. Adapun informasi yang dapat dipaparkan mengenai variasi campur kode dapat mulai dilihat dari cuplikan dialog di bawah ini.

Mredah : Dasar banie?

'Apa yang mendasarinya?'

Tualen : Nanang sing ada pamrih. Sing ngelah beban adane.

'Ayah tidak ada pamrih. Tidak punya beban namanya.'

Mredah : To ka keto?

'Mengapa begitu?'

Cuplikan dialog di atas menyiratkan penggunaan variasi campur kode bahasa dalam suatu dialog yang terjadi antara Mredah dan Tualen. Campur kode dalam dilihat dari ujaran kalimat Tualen yaitu pada kata "pamrih" dan "beban". Kedua kata ini merupakan kosa kata dari bahasa Indonesia yang diselipkan dalam tuturan kalimat bahasa Bali. Hal ini disebabkan oleh karena tidak ada kosa-kata, frase, maupun istilah dalam bahasa Bali yang dapat mengacu pada makna 'pamrih' dan 'beban' tersebut. Dengan demikian, mau tidak mau, kedua kata 
tersebut memang harus muncul/ dituturkan oleh dalang untuk menyampaikan pokok pikirannya pada saat itu. Hal ini merupakan keuntungan bagi dalang dan penonton sehingga keduanya lebih mudah untuk memahami pokok pikiran atau ide dari sang dalang yang dituangkan dalam dialognya. Selain itu, perhatikan juga cuplikan dialog di bawah ini.

Mredah : Mawin sing bani mature?

'Apa yang menyebabkan tidak berani mengoreksi?'

Tualen : $\quad$ Nyanan matur pelih nyen, pecata nya nyen. Kepentingan ada to, nanang tera ada kepentingan. Kepentingan nanang besik, nanang dot nepukin pemimpin ne luih, ajume ken rakyate, sing Ida gen liang, nanang masih milu demen.

'Kalau salah mengoreksi, nanti kamu dipecat. Ada kepentingan namanya itu, kalau ayah tidak ada kepentingan. Kepentingan ayah hanya satu, ayah hanya ingin melihat pemimpin yang baik. Dikagumi oleh rakyat. Tidak hanya beliau yang senang, ayah juga ikut senang.'

Cuplikan dialog di atas juga menyiratkan adanya variasi campurkodeyang dituturkan oleh dalang Cenk Blonk melalui tokoh Mredah dan Tualen. Adapun percampuran kode yang terlihat adalah dengan ditemukannya kata kata "kepentingan", "pemimpin", dan "rakyat". Ketiga kata ini adalah kosa kata bahasa Indonesia yang diselipkan dalam tuturan berbahasa Bali. Ketiganya sebenarnya memiliki padanan dalam bahasa Bali yaitu "kepentingan" 'bebuat', "pemimpin" 'ratu/ raja', "rakyat" 'panjak'. Dalang tidak memilih untuk menggunakan kosa kata yang berbahasa Bali melainkan lebih memilih yang berbahasa Indonesia/ bercampur kode pasti disebabkan oleh berbagai hal. Hal ini juga memberikan efek positif bagi dalang dan penonton. Dalang mendapatkan kemudahan dalam menuangkan idenya melalui penggunaan kata-kata tersebut untuk mengacu pada makna yang dimaksud, dan dari segi lain, penonton juga lebih mudah menangkap maksud dan memahami apa yang menjadi ide pokok dari pikiran dalang. Meskipun, bisa menggunakan bentuk-bentuk kata bersangkutan dalam bahasa Balinya juga bisa dimengerti, akan tetapi penggunaan dari kosa kata bahasa Indonesianya tentu akan lebih mudah lagi untuk dimengerti. Perihal sebab-sebab dari dalang untuk bercampur kode akan dipaparkan pada bab selanjutnya.

\section{Alih Kode (Code Switching)}

Salah satu wujud diksi retorika lain dalang Cenk Blonk adalah alih kode. Peristiwa alih kode dapat dipandang dari sudut bahasa yang dipakai dan dari penutur itu sendiri. Hal ini merupakan salah satu jenis variasi retorika yang perlu untuk dicermati. Bilamana kita melihat dari segi bahasa yang digunakan dalam pertunjukan, maka alih kode yang ada pada dialog dalam pertunjukan wayang Cenk Blonk menunjukkan terjadinya perubahan pemakaian bahasa dari bahasa Bali ke bahasa Indonesia serta perubahan pemakaian bahasa dari bahasa Bali ke bahasa Inggris. Dalang Cenk Blonk menguasai sedikitnya dua bahasa yang berbeda. Dalam hal ini, dalang tersebut disebut dengan dalang bilingual. Selain itu, Cenk Blonk juga menguasai bahasa lain yaitu bahasa Jawa Kuna (bahasa kawi), serta tidak sedikit pula yang menguasai bahasa asing seperti bahasa Inggris. Dengan demikian, dalang Cenk Blonk dapat dikatakan sebagai dalang yang multilingual. Dalam percakapan yang dilakukan oleh dalang multlingual melalui dialog tokoh-tokohnya, akan timbul kecenderungan terjadinya peristiwa alih kode. Peristiwa alih kode dapat dijumpai dalam cuplikan dialog berikut ini.

Peranda : Yogia.

$\begin{array}{ll}\text { Sokir } & \text { : 'Benar.' } \\ & \text { : 'Bagih. Once again! } \\ & \text { :Bahl Sekali lagi!' }\end{array}$

Peranda : : Beh, once again. Mara ci dueg, jeg bapa ajak ci makaca to.

'Wah, baru kamu pintar, bapa kamu ajak bercermin.'

Sokir $\quad:$ Anu, wawanin malih pisan! 'Anu, ulangi sekali lagi!'

Cuplikan dialog antara Peranda dan Sokir di atas memberikan uraian bahwa telah terjadi peristiwa alih kode. Awal mulanya kedua tokoh tersebut berdialog dengan menggunakan bahasa Bali. Pada suatu ketika, Peranda kemudian beralih dengan mengucapkan kata "yogya" yang merupakan kosa kata bahasa Jawa Kuna yang artinya "benar". Serentak setelah itu pula, Sokir menjawab dengan mengucapkan "once again" yang merupakan frasa bahasa Inggris yang berarti "sekali lagi". Peralihan bahasa yang terjadi dari bahasa Bali ke bahasa Inggris dilakukan dalang Cenk Blonk melalui tokoh (Sokir) karena dia ingin melucu dan sekaligus pamer akan kemampuan bahasa Inggrisnya.

Variasi retorika berupa diksi peralihan bahasa dari Bahasa Bali ke bahasa Inggris ini berada dalam 
tataran morfosintaksis, di mana sebuah kata bisa sekaligus berfungsi sebagai kalimat. Diksi peralihan bahasa dilakukan karena dalang Cenk Blonk ingin menunjukkan kemampuan berbahasa Inggrisnya dan sekaligus melucu. Penggunaan ungkapan istilah tersebut dilakukan karena akan mudah dipahami apabila digunakan sesuai dengan bahasa aslinya, karena istilah tersebut diambil dari perbendaharaan kosa kata bahasa asing. Hal ini senada dengan komponen Ends atau 'Tujuan Pembicaraan' yang merupakan komponen ketiga dari kedelapan komponen SPEAKING. Suatu variasi retorika dalam tuturan digunakan untuk menyampaikan informasi dengan menunjukkan suatu kesan tertentu terhadap penonton. Selain peralihan dari bahasa Bali Ke Bahasa Inggris, ada pula peralihan bahasa yang terjadi adalah peralihan dari bahasa Bali ke bahasa Indonesia. Awalnya Tualen menggunakan bahasa Bali dalam berdialog dengan Mredah. Mredah pun menjawabnya dengan bahasa Bali. Kemudian, Tualen beralih kode dengan menggunakan bahasa Indonesia. Berikut dialognya:

Mredah : Kuda?

$\begin{array}{ll}\text { Tualen : } & \begin{array}{l}\text { 'Bua } \\ \text { 'Dua' }\end{array} \\ \text { Mredah : } & \begin{array}{l}\text { Pura dua? } \\ \text { 'Pura dua?' }\end{array} \\ \text { Tualen : } & \text { Pura-pura. }\end{array}$

Peralihan bahasa dari bahasa Bali ke bahasa Indonesia dilakukan oleh dalang melalui tokoh Tualen. Hal tersebut dilakukan karena dalang ingin melucu sekaligus bermaksud menyindir orang-orang yang mengharapkan pamrih dari bantuan yang mereka berikan pada orang lain. Komponen Ends (tujuan pembicaraan) adalah yang komponen yang ambil andil dalam peristiwa ini. Ends dalam kesempatan ini dimungkinkan terjadi karena adanya dukungan dari Setting yang merujuk pada suasana / situasi tutur. Dialog di atas terjadi dalam sebuah situasi tidak resmi. Suatu variasi retorika yang biasanya menggunakan satu variasi bahasa dalam satu macam situasi, tetapi variasi bahasa itu juga digunakan dalam situasi lain asalkan pokok (topik) pembicaraannya sama dengan situasi pertama (jendra, 1991: 122). Dalam dialog antar tokoh-tokoh pada pertunjukan wayang Cenk Blonk masa kini, ditemukan pemakaian dua macam ragam bahasa, yakni ragam tinggi atau yang disebut bahasa alus, dan ragam rendah atau yang disebut bahasa kasar. Perubahan semacam ini disebut dengan Metaphorical Code Switching (alih kode metaforik).
Selain itu, ada juga variasi retorika yang berwujud Situational Code Switching (alih kode situasional). Variasi ini adalah jenis alih kode yang terjadi apabila seseorang selalu mengganti variasi bahasanya pada setiap perubahan situasi. Dalam suatu masyarakat, keadaan tersebut sering dikatakan sebagai perubahan bilingual atau disebut pula multilingual. Individuyang bersangkutan biasanya dikatakan sebagai seorang dwibahasawan atau seorang multibahasawan yakni orang yang menguasai dua atau lebih bahasa dalam waktu yang bersamaan. Dalam pertunjukan wayang Cenk Blonk, situational code switching ini terjadi berkaitan dengan perubahan isi pokok pembicaraan (topik). Peralihan topik pembicaraan mengakibatkan bahasa yang digunakan pun ikut beralih. Hal ini disebabkan oleh adanya perubahan situasi / setting. Wujud alih kode dapat berupa perpindahan antar bahasa, antar tingkatan tutur, antar dialek, dan antar ragam. Perpindahan antar bahasa misalnya terjadi antara bahasa Bali dan bahasa asing, antara bahasa Bali dan bahasa Indonesia, dan antara bahasa Bali dan bahasa Jawa Kuna (Kawi). Perpindahan antar tingkatan tutur dalam bahasa Bali misalnya terjadi antara tingkatan tutur kasar (tidak hormat) dengan tingkat tutur halus (hormat). Variasi retorika yang berwujud alih kode berupa peralihan speech level (tingkat tutur) akan diuraikan secara lebih rinci di bawah ini.

\section{Tingkatan Tutur Bahasa Bali (Anggah- Ungguhing Basa Bali)}

Variasi Retorika yang berkaitan dengan speech level dalam bahasa Bali atau lebih dikenal dengan AnggahUngguhing Basa Bali memiliki ciri-ciri tertentu yang membedakannya dengan dengan peristiwa bahasa lainnya. Anggah-Ungguhing Basa Bali merujuk pada tingkatan-tingkatan tuturan dalam berbahasa. Ciriciri itu berhubungan dengan latar belakang situasi (lingkungan) sebagai ciri luarnya dan juga berkaitan dengan partisipan dan bahasa yang digunakan sebagai ciri yang bersifat ke dalam. Secara lebih spesifik, variasi semacam ini akan sangat terlihat pada pemilihan kata/ diksi untuk merujuk pada partisipan (penutur dan lawan tutur). Anggah-ungguhing Basa Bali pada prinsipnya menekankan pada penggunaan kosa kata yang tepat untuk mengacu pada partisipan yang tepat. Anggah-ungguhing ini adalah tingkatan bahasa Bali yang mengacu pada penggunaan kruna 'kata' sesuai dengan rujukan terhadap pembicara dan lawan bicara yang dapat dibagi menjadi beberapa bagian yaitu 1) Kruna Alus (Kruna Alus Singgih, Kruna Alus Mider, Kruna Alur Madya, Kruna Alus 
Sor), 2) Kruna Mider, 3) Kruna Andap/ Kepara, dan 4) Kruna Kasar

Kruna Alus adalah semua kata yang digunakan dalam tuturan yang bersifat halus/ hormat. Kruna Alus ini dapat dibagi menjadi 4 bagian, tergantung dari rujukan terhadap partisipan (pembicara/ lawan bicara). 1 a) Kruna Alus Singgih adalah pilihan kata-kata yang digunakan dalam tuturan kalimat bahasa halus/ hormat apabila sesuatu merujuk pada lawan bicara yang patut dihormati seperti orang tua, guru, Tuhan, pendeta, tamu, dan lain sebagainya. 1 b) Kruna Alus Mider adalah pilihan kata-kata digunakan dalam tuturan kalimat bahasa halus/ hormat apabila sesuatu merujuk pada siapapun juga baik pembicara dan lawan bicara, karena katakata yang tergolong Alus Mider ini sifatnya luas/ dapat berdistribusi terhadap semua partisipan pada kalimat ragam halus/ hormat, dan hanya memiliki bentuk halus 1 saja (tidak memiliki banyak bentuk sinonim halus). 1 c) Kruna Alus Madya adalah pilihan kata-kata yang digunakan dalam tuturan kalimat bahasa halus/ hormat yang dapat mengacu kepada semua partisipan. Kesan makna kata-kata jenis ini adalah halus/ hormat yang berada di tengahtengah. Biasanya jenis kruna alus ini digunakan untuk merujuk pada partisipan/ lawan bicara yang belum dikenal sebelumnya. Kruna-kruna bentuk ini tentu memiliki padanan lain dalam bentuk singgih dan sornya. 1d) Kruna Alus Sor digunakan dalam tuturan kalimat bahasa halus/ hormat apabila sesuatu mengacu pada diri sendiri. Ini merupakan kebalikan dari bentuk Alus Singgih yang digunakan untuk mengacu pada sesuatu yang merujuk pada lawan bicara yang patut untuk dihormati.

Kruna Mider adalah pilihan kata-kata yang dapat digunakan dalam bahasa Bali ragam standar/ biasa dan ragam halus/ hormat. Kruna Mider distribusinya sangat luas. Kata-kata yang tergolong Kruna Mider ini dapat digunakan dalam semua jenis tingkatan bahasa Bali mulai dari tingkat kasar hingga ke tingkat halus karena jenis kruna ini tidak memiliki sinonim/ bentuk lain dalam bahasa Bali sebagai padanannya. Kata-kata yang tergolong dalam Kruna Mider ini dapat mengacu pada semua partisipan, dan segala bentuk tingkatan bahasa. Kruna Andap/ Kepara adalah pilihan kata-kata dalam bahasa Bali yang bersifat lumrah atau kesannya biasa-biasa saja, tidak halus dan tidak kasar. Kata-kata yang tergolong ke dalamnya biasanya digunakan ketika berkomunikasi dalam kehidupan sehari-hari dalam ranah non formal atau pada ragam santai. Pada kesempatan yang sama pula, terkadang atau sering juga disisipkan Kruna Kasar atau kata-kata yang bersifat kasar terutamanya ketika bersenda gurau dengan kawan atau pada saat bertengkar. Kata-kata ini dapat merujuk kepada semua partisipan. Kata-kata yang tergolong Kruna Kasar ini memiliki makna emosi yang bersifat sangat akrab, kesal/ marah tergantung dari partisipan dan situasi saat berkomunikasi (Partisipan dan Setting).

Berdasarkan penelitian yang telah dilakukan, ditemukan beberapa variasi tingkat tutur dalam pertunjukan wayang Cenk Blonk yakni fungsi tiaptiap bahasa disesuaikan dengan latar belakang sosial tokoh-tokohnya. Masyarakat Bali hingga saat ini mengaplikasikan sistem wangsa yang secara langsung akan berpengaruh terhadap usaha seseorang dalam pemilihan variasi dan pemakaian bahasanya. Pemilihan dan pemakaian bahasa juga berkaitan erat dengan status sosial seseorang. Pemilihan dan pemakaian bahasa yang dipengaruhi oleh status sosial juga terjadi dalam pertunjukan wayang Cenk Blonk.

Mredah : Duh, sepet alet bon kantonge. 'Aduh, sepat sekali bau kantongnya.'

Tualen : Tengil iba! Oyong iba ditu! 'Diam kamu! Diamlah kamu di sana! Iring dabdabang Ratu, iring! 'Ayo bersiap-siap Tuanku, ayo!

Anoman: Yatna Tualen? 'Siap Tualen?'

Tualen : Ngraris Ratu! 'Silakan tuanku!

Cuplikan dialog di atas menunjukkan adanya variasi retorika dalam percakapan antara Anoman, Tualen, dan Mredah saat berkomunikasi. Bahasa yang digunakan oleh Tualen ketika berbicara dengan Anoman adalah bahasa Bali alus. Penggunaan bahasa Bali alus dikarenakan oleh kedudukan dirinya yang merupakan seorang abdi. Lain halnya pada percakapan Tualen dengan Mredah yang menggunakan bahasa Bali lumbrah (kapara) atau bahasa Bali yang kesannya umum/ biasa-biasa saja karena mereka berstatus sosial sama. Dengan demikian, terlihat jelas bahwa variasi retorika terkait speech level yang terjadi disesuaikan dengan latar belakang sosial atau status sosial tokoh-tokohnya. Komponen norms atau norma tutur merupakan komponen yang ambil andil dalam peristiwa ini. Selain itu, komponen key "nada tutur" yang merujuk pada nada, cara, dan motivasi di mana suatu tindakan 
dapat dilakukan dalam bertutur. Nada Tutur dalam hal ini bersifat verbal yang menunjuk pada warna serius, tegang, dan kasar.

\section{Singkatan/ Abreviasi}

Abreviasi secara sederhana merupakan sebuah huruf atau sekumpulan huruf sebagai bentuk pendek dari sebuah atau beberapa kata. Selain itu, abreviasi juga mencakup proses pemenggalan satu atau beberapa bagian leksem atau kombinasi leksem sehingga terjadilah bentuk baru yang berstatus kata. Istilah lain untuk Abreviasi adalah pemendekan, sedangkan hasil dari prosesnya disebut dengan kependekan. Apabila dilihat dari karakter contohnya, untuk sementara ini abreviasi dapat digolongkan menjadi dua jenis yaitu akronim dan lakuran. Ulasan di bawah ini dapat dijadikan gambaran mengenai akromin dan lakuran yang dimaksud.

\section{Akronim}

Akronim adalah kepedekan yang berupa gabungan huruf atau suku kata, atau bagian lain yang ditulis dan dilafalkan sebagai kata yang wajar. Akronim biasanya dibuat dan digunakan untuk meraih kesan efisiensi dalam pengucapan dan penulisan suatu kata, istilah, maupun frasa. Banyak sekali contoh penggunaan akronim dalam bahasa Bali dan bahasa Indonesia. Hasil pemendekan tersebut dirasa lebih efektif dan efisien dalam konteks penggunaannya ketika berkomunikasi. Sebagai contoh misalnya kata/ frase "BPD (Bali)" yang merupakan akronim dari "Bank Pembangunan Daerah" (Bali) sudah sangat lumrah diketahui dan digunakan oleh penutur bahasa Bali. Dalam pertunjukan wayang Cenk Blonk dijumpai juga contoh-contoh penggunaan akronim. Dilihat dari jenis maupun fungsi kegunaannya, akronim dalam pertunjukan wayang Cenk Blonk dapat dibedakan menjadi 3 yaitu akronim umum, akronim jargon, dan akronim umum yang dijargonkan. Perhatikan cuplikan dialog di bawah ini.

\begin{tabular}{|c|c|}
\hline Sangut: & $\begin{array}{l}\text { Bila perlu cari, tagih nomor KTPne! } \\
\text { 'Bila perlu minta nomor KTPnya!' }\end{array}$ \\
\hline Blonk : & $\begin{array}{l}\text { Kayang nagih KTP pra mase? } \\
\text { 'Sampai minta KTP juga?' }\end{array}$ \\
\hline Sangut: & $\begin{array}{l}\text { aa.. } \\
\text { 'ya.' }\end{array}$ \\
\hline Blonk : & $\begin{array}{l}\text { Ba baang KTP? } \\
\text { 'Setelah diberi KTP?' }\end{array}$ \\
\hline Sangut: & $\begin{array}{l}\text { Tagih nomor nomor telpon handponne! } \\
\text { 'Minta nomor nomor telepon atau } \\
\text { handphonenya! }\end{array}$ \\
\hline
\end{tabular}

Cuplikan dialog di atas menunjukkan bahwa dalang Cenk Blonk menggunakan akronim umum dalam dialognya. Akronim yang digunakan masih bersifat lumbrah karena kepanjangan dan maknanya diketahui oleh banyak orang. Dalam kesempatan ini, dalang menggunakan kata "KTP" yang merupakan akronim dari "Kartu Tanda Penduduk". Penggunaan akronim umum ini sebenarnya tidak begitu berdampak signifikan sebagai varian retorika, namun dirasa masih perlu untuk diuraikan sebagai pengenalan terhadap peranan akronim sebagai salah satu pembangun variasi retorika dalam pertunjukan wayang.

Selain contoh akronim di atas, Akronim lain yang dipilih bukan merupakan contoh akronim umum saja yang diambil dari khazanah bahasa biasanya. Akronim dalam hal ini berafiliasi dengan bahasa perseorangan yaitu gaya bahasa khas dalang Cenk Blonk. Bahasa khas suatu kelompok atau perseorangan disebut dengan jargon. Jargon biasanya tidak dipahami oleh orang banyak atau oleh orang dari bidang kehidupan lain maupun orang dengan jenis dan karakter bahasa yang berbeda. Dalam hal ini, hanya dalang Cenk Blonk dan komunitasnya saja mengetahui maksud dari akronim tersebut, terkecuali dalang menyampaikan langsung kepada audience. Oleh sebab itu, akronim semacam ini disebut dengan akronim jargon. Perhatikan kutipan dialog berikut ini.

Cuplikan I

Peranda : Sokir.....!

'Sokir...!'.

Sokir : : Titiang Peranda.

'(ya) Saya pendeta'.

Peranda : Ci peranda?

'Kamu Pendeta?'

Sokir : Beh, biin pelih to, $\underline{P M}$, perandae nah! Jeg, "Pait Makilit" ne.

'Wah, itu salah lagi, PM, ya pendetanya ya. Jeg licik.'

Peranda : Jeg, titiang peranda.

'Jeg, saya pendeta.'

Sokir : punapimen?

'Bagaimana seharusnya?'

Cuplikan II

Sangut : $\quad$ Ne mawinan kuren cange madan

Bu Etik, wireh panak cange ane paling keliha madan Ni Luh Putu Etik Prastika Sintia Dewi Ningrat Ningsih Ningrum $\underline{\underline{S G M}}$.

'Yang menyebabkan istriku bernama 
$\mathrm{Bu}$ Etik, karena anak sulungku bernama Ni Luh Putu Etik Prastika Sintia Dewi Ningrat Ningsih Ningrum SGM.'

Delem : $\quad$ Mih, dewa ratu, jeg makudus bungut cie. Nyen, nyen, nyen?

'Astaga, panjang sekali omonganmu. Siapa, siapa, siapa?

Sangut : $\quad$ Ni Luh Putu Etik Prastika Sintia Dewi Ningrat Ningsih Ningrum SGM.

Ni Luh Putu Etik Prastika Sintia Dewi Ningrat Ningsih Ningrum SGM.'

Delem : $\quad$ SGM to apa?

'SGM itu apa?'

Sangut : $\quad$ Singkatan.

'Singkatan'.

Delem : $\quad$ SGM?

'SGM?'

Sangut : $\quad$ Santai, gaul, melankolis.

Pada kutipan I ditemukan "PM" yang merupakan akronim dari frase "Pait Makilit" yang bermakna 'sangat pahit', yang merupakan suatu ungkapan di mana dalam bahasa Indonesia dapat dipadankan dengan frase 'sangat kikir'. Pada kutipan II ditemukan SGM yang merupakan akronim dari frase "Santai, Gaul Melankolis". Penonton tidak akan mengerti dengan maksud dari akronim tersebut apabila dalang tidak menyebutkan bentuk panjang/ kepanjangannya. Inilah yang dimaksud dengan akronim jargon, di mana suatu akronim dibuat oleh dalang sendiri dengan interpretasi sendiri dan maknanya langsung disampaikan kepada penonton sehingga pemahaman dalang terhadap akronim tersebut tersampaikan. Hal ini merupakan salah satu variasi retorika pilihan kata akronim yang membangun lakon kreatif dan menarik. Perhatikan cuplikan dialog di bawah ini.

Tualen : $\quad$ Pang da nyen I dewa dadi pemimpin kena sakit $\underline{A I D S}$, keweh pemimpine kena sakit AIDS.

'Supaya jangan sampai kamu menjadi pemimpin yang kena sakit AIDS. Sulit jika pemimpin kena sakit AIDS.'

Mredah : Pemimpin apa kena sakit aids?

'Pemimpin macam apa kena sakit aids?'

Tualen : $\quad$ Liu pemimpin kena sakit aids. 'Banyak pemimpin kena sakit AIDS.'

Mredah : AIDS e to?

$\begin{array}{ll} & \text { 'AIDS itu apa? } \\ \text { Tualen : } & \text { A, I, D, S. } \\ \text { Mredah : } & \text { A? } \\ \text { Tualen : } & \text { Angkuh. } \\ \text { Mredah : } & \text { I? } \\ \text { Tualen : } & \text { Iri hati } \\ \text { Mredah : } & \text { D? } \\ \text { Tualen : } & \text { Dengki. } \\ \text { Mredah : } & \text { S? } \\ \text { Tualen : } & \text { Sombong. }\end{array}$

Cuplikan dialog di atas menunjukkan adanya contoh kata akronim yang disajikan. Kata yang dimaksud adalah "AIDS". AIDS adalah akronim umum dan dikenal hampir oleh semua orang penutur bahasa Bali, bahasa Indonesia, dan bahasa Inggris. AIDS diketahui secara luas merupakan akronim dari 'Acquired Immune Deficiency Syndrome' yang merupakan tahapan akhir dari penyakit infeksi human immunodeficiency virus (HIV). "AIDS" dipahami oleh banyak orang sebagai suatu penyakit yang diakibatkan oleh kebiasaan seringnya seseorang berbuat amoral dan bergonta-ganti pasangan. Akan tetapi, “AIDS” dalam kesempatan ini diplesetkan oleh dalang Cenk Blonk. Interpretasi dan pemaknaan “AIDS” dari dalang Cenk Blonk adalah akronim "Angkuh, Iri hati, Dengki, Sombong”. Awal mulanya penonton menginterpretasikan "AIDS" sebagai suatu penyakit, akan tetapi setelah dalang Cenk menyampaikan maksud sebenarnya, sontak penonton mengerti dan tertawa. Memlesetkan akronim umum dengan pemaknaan khas sendiri bisa dilakukan untuk sekedar membuat lelucon, asalkan penonton diberikan pemahaman terhadap makna yang kita ingin sampaikan. Dengan demikian, variasi retorika semacam ini sanggup untuk membangun sebuah narasi dialog yang menarik dalam pertunjukan wayang.

\section{Lakuran (Portmanteau)}

Lakuran (portmanteau) adalah kata baru yang terbentuk dari hasil penggabungan dua atau lebih kata atau bagian kata sehingga dihasilkan arti gabungan dari dua kata pembentuknya. Contoh yang sering kita dengar adalah kata "sinetron" yang merupakan penggabungan dari (sinema dan elektronik), "Surel” (surat dan elektronik). Selain itu, ada juga contoh yang dikenal luas di seluruh dunia seperti misalnya kata "cyborg" yang merupakan penggabungan dari (cybernetic dan organism) yang bermakna 'organisme sibernetik'. Rupanya, dalang Cenk Blonk juga mampu mengaplikasikan 
penggabungan ini dan membangun suatu contoh lakuran dan digunakan dalam dialognya. Perhatikan cuplikan dialog di bawah ini.

Tualen : Tiang bin, ajak tiang liu buin mai. Tiang ngelah persatuan balian

'Saya apalagi, malahan saya datang berbanyak ke sini. Saya memiliki komunitas/ persatuan dukun”.

Sangut : Napi nika?

'Apakah itu?'

Tualen : Ibasnia adanne

'Ibasnia namanya'.

Sangut :Ibasnia ae?

"Ibasnia ya?

Tualen :Ikatan Balian SeduNIA. Ma nak malunan pesu ragae! Tiang bakal ngalih ruang tiang.

'Ikatan dukun Sedunia. Silakan anda keluar duluan! Saya akan mencari rekan saya'.

Sangut : Nggih, nggih, nggih.

'Ya, ya, ya'.

Pada cuplikan dialog di atas ada sebuah contoh lakuran yaitu kata "Ibasnia". Penonton sejatinya tidak memahami maksud dari dalang mengenai kata "ibasnia" tersebut. Hal ini dipahami oleh dalang dan sengaja dilakukan untuk sekedar membuat lelucon. Lelucon ini akhirnya bisa dipahami oleh penonton, karena dalang melalui tokoh Tualen menyampaikan secara langsung mengenai lakuran "Ibasnia" tersebut. Sesuai dengan apa yang disampaikan secara langsung oleh dalang melalui tokoh Tualen, "Ibasnia" merupakan sebuah kata yang merupakan penggabungan dari beberapa kata yaitu (ikatan, balian, dan sedunia). Dengan ini, tentu saja lakuran adalah salah satu jenis variasi retorika yang dapat dimanfaatkan sebagai sebuah lelucon dalam pertunjukan wayang.

Gaya Bahasa Simile (Sesawangan/Pepindan) Sesawangan atau pepindan dapat diartikan sama dengan perumpamaan. Yang diumpamakan atau dikhiaskan adalah keadaan budi pekerti seseorang, gerak-gerik, keadaan anggota badan dan lain sebagainya, dibandingkan dengan alam sekitarnya. Biasanya setiap kalimat sesawangan dimulai dengan kata buka, alah, dan sejenisnya. Variasi retorika dengan gaya bahasa semacam ini juga banyak ditemukan dalam pertunjukan wayang Cenk Blonk. Salah satu contoh yang ditemukan yakni pada kalimat
"Yan wimbang aji dewa dadi ratu, dadi pemimpin, tulia kadi raab i genteng ngoyong ba duur. I genteng sing nyidaang tekek ngoyong di duur, yan sing $i$ reng, $i$ usuk, ne natakin beten". Kata 'tulia" dalam bahasa Bali yang bermakna 'bagaikan' adalah penanda / marker dari gaya bahasa jenis ini.

Di dalam Basita Paribasa oleh I Wayan Simpen AB, istilah sesawangan dan pepindan dibedakan yaitu:

1. Pepindan (perumpamaan) itu memakai kata benda yang mendapatkan awalan, misalnya alise madon intaran.

2. Sesawangan (pengumpamaan) itu memakai kata-kata seperti buka, kadi, luir, alah, pendah kadi, waluya kadi,misalnya: alise waluya don intaran.

Namun demikian, beberapa ahli berpendapat bahwa pepindan dan sesawangan dianggap sama saja maksudnya. Ada pun contoh lain adalah sebagai berikut.

1. Paliate kadi tatit 'Tatapan matanya tajam bagaikan sambaran petir'

2. Galakne buka cicing borosan 'Galaknya bagaikan anjing pemburu'

\section{Gaya Bahasa Ironi (Sesimbing)}

Sesimbing berasal dari kata dasar simbing kemudian direduplikasikan sehingga menjadi sesimbing yang artinya sindiran. Sesimbing atau sindiran dalam bahasa Indonesia maupun bahasa Bali ada yang bersifat tajam (pedas) dan ada yang bersifat lemah. Pada umumnya paribasa itu merupakan sindiran bagi kita. Oleh karena itu, contoh-contoh dalam ; sesonggan, sesenggakan, sloka, dan lain sebagainya akan muncul dalam sesimbing. Akan tetapi, sesimbing yang diterjemahkan dengan sindiran pada umumnya yang sifatnya agak tajam. Berkenaan dengan hal itu, dalam sesimbing atau sindiran kadang-kadang kita jumpai kata-kata yang maksudnya terbalik dari apa yang dikatakannya itu, misalnya yang kecil dikatakan besar, yang buruk dikatakan bagus, dan lain sebagainya. Dalam pertunjukan wayang Cenk Blonk, gaya bahasa ironi ini menjadi salah satu variasi retorika yang sering digunakan. Hal tersebut dapat dijumpai dari tuturan, Nah keto, jani I dewa anggona generasi muda, generasi penerus, da I dewa enggal kena provokator, kena hasutan! Ingetang di manise ngamanesin. Da I dewa bes iju-iju nampi munyi manis! Ne jani lautang ciriang, ciriang baktin I dewa kapining reraman I dewane! 
Alih kepung Ida Bhatara Rama! Wireh Ida mula bakal ngardi karahayuan ikanang jagat. Ida mula seleg nangun yadnya, nyambat Widhi, nyambat Dewa ngawinang gumine landuh wireh Ida mula tosen Bhatara Wisnu. Kepung, kepung cening!

Dalam bahasa indonesia, tuturan tersebut dapat dimaknai sebagai berikut: 'Nah begitu, sekarang kamu sebagai generasi muda, generasi penerus jangan sampai kamu cepat terkena provokasi, terkena hasutan! Ingat kata-kata manis bisa membawa sengsara. Jangan sampai menerima kata-kata manis kamu segera melakukan sesuatu tanpa berpikir terlebih dahulu. Sekarang segera tunjukkan rasa baktimu kepada orang tuamu. Cari dan kejar Bhatara Rama! Karena beliau memang akan membuat dunia ini aman sentosa. Beliau memang taat melaksanakan yadnya, menyebut nama Tuhan, menyebut nama dewa yang membuat dunia ini makmur karena beliau merupakan jelmaan Dewa Wisnu. Kejar, kejarlah nak!'

Cuplikan ujaran di atas menunjukkan adanya contoh variasi retorika gaya bahasa yang termasuk ke dalam sesimbing, dibuktikan dengan adanya klausa "manise ngamanesin" "kata-kata manis bisa membawa sengsara'. Dalam bahasa Indonesia, sesimbing disejajarkan dengan majas Ironi yang termasuk ke dalam ragam majas pertentangan. Ironi adalah majas yang menyatakan makna yang bertentangan, dengan maksud mengolok-olok atau sejenisnya. Maksud itu dapat tercapai dengan mengemukakan: 1) makna yang berlawanan dengan makna yang sebenarnya; 2) ketaksesuaian antara suasana yang diketengahkan dengan kenyataan yang mendasarinya dan; 3) ketaksesuaian antara harapan dan kenyataan. Dengan demikian dapat dikatakan bahwa ironi adalah majas yang mengimplikasikan sesuatu yang nyata-nyata berbeda. Bahkan ada kalanya bertentangan dengan yang sebenarnya dikatakan itu. Ironi ringan merupakan bentuk humor tetapi ironi keras merupakan bentuk sarkasme atau satire walau batasan yang tegas antara hal-hal itu sangat sukar dibuat dan jarang memuaskan orang.

\section{SIMPULAN}

Berdasarkan penelitian yang telah dilakukan terhadap pertunjukan wayang Cenk Blonk, dapat disimpulkan bahwa I Wayan Nardayana/ dalang Cenk Blonk adalah seorang seniman yang mampu menggebrak dunia seni pertunjukan wayang kulit Bali dengan berbagai langkah dan inovasi yang sangat kreatif. Inovasi yang dilakukan meliputi inovasi dalam tata iringan musik/ gamelan, seni suara, tata teknik pentas, gerak wayang/ tetikesan, dan antawacana/ retorika bahasa. Retorika dalang Cenk Blonk mempunyai ciri khas tersendiri dan menawarkan berbagai variasi retoris sehingga mampu membangun suatu lakon pertunjukan wayang yang menarik untuk disimak. Variasi retorika dalang Cenk Blonk meliputi dua hal yakni diksi dan gaya bahasa. Diksi/ pilihan kata dalam Pertunjukan Wayang Cenk Blonk meliputi Campur Kode (Code Mixxing), Alih Kode (Code Switching), Tingkatan Tutur Bahasa Bali (Anggah-Ungguhing Basa Bali), serta Singkatan/ Abreviasi yang terbagi menjadi Akronim dan Lakuran (Portmanteau). Penggunaan gaya bahasa yang ditemukan meliputi Gaya Bahasa Simile (Sesawangan/ Pepindan), dan Gaya Bahasa Ironi (sesimbing). Diksi dan gaya bahasa tersebut tersusun menjadi suatu kesatuan retoris dalam membangun lakon yang sarat akan nilai-nilai penting untuk dapat disampaikan kepada masyarakat, namun juga sangat menarik untuk disaksikan.

\section{DAFTAR RUJUKAN}

Abidin, Yusuf Zainal. 2013. Pengantar Retorika. Bandung: Pustaka Setia.

Appel, R. Dan Muysken, P. 1999. Language Contact and Billingualism. Institut For General Linguistics: University Of Amsterdam.

Aslinda dan Leni Syafyahya. 2007. Pengantar Sosiolinguistik. Bandung: Redika Aditama.

Hornberger, Nancy H. \& Sandra Lee Mckay. 2015. Sociolinguistics and Language Education. Toronto: Multilingual Matters

Kridalaksana, Harimurti. 2009. Kamus Linguistik. (Edisi Keempat). Jakarta: PT Gramedia Pustaka Utama.

Koentjarangingrat. 2009. Khasanah Antropologi. Jakarta: Refika

Pramita, Puri. 2015. "Studi Tentang Retorika Dakwah Yusuf Mansur dan Pemanfaatannya Sebagai Bahan Ajar Berbicara”. Universitas Pendidikan Indonesia

Putra, Gumana. 2017. "Alih Kode dalam Seni Pertunjukan Wayang Kulit Inovatif di Bali”. Denpasar: Institut Seni Indonesia Denpasar 
Rahardi, Kunjana. 2011. Sosiolinguistik, Kode dan Alih Kode. Yogyakarta: Pustaka Pelajar.

Sulistyarini, Dhanik. \& Anna Gustina Zainal. 2020. Buku Ajar Retorika. Jakarta: CV. A.A. Rizky.

Sutrisno, Isbandi. \& Ida Wiendijarti. 2014. "Kajian Retorika Untuk Pengembangan Pengetahuan dan Keterampilan Berpidato. Yogyakarta: FISIP UPN Veteran

Tinggen, I Nengah. 1988. Aneka Rupa Paribasa Bali. Denpasar: Rhika Dewata 